\title{
Islam, Kristen, dan Aruh: Agama Baru dan Perubahan Agroekosistem Peladang Dayak Loksado, Kalimantan
}

\author{
Moh. Soehadha \\ Fakultas Ushuluddin dan Pemikiran Islam Universitas Islam Negeri Sunan Kalijaga, Yogyakarta \\ (e-mail: suhadhaa@yahoo.co.id)
}

\begin{abstract}
This article focuses on the influence of new religions (Islam and Christianity) to the changing of agroecosystem in Dayak Loksado. In line with the government policy in employing modern agricultural farming, spreading new religions (Islam and Christianity) have affected the changing of traditional farming to the modern one. This research aims to know the influence of religious conversion in an agroecosystem in Dayak Loksado and several influential factors and also the impact of that system. Using qualitative as an approach, the data are collected from in-depth interview focused on special region named Balai Padang, Malinau, Loksado. The result of this research shows that conversion to a new religion has changed agroecosystem in Dayak Loksado in terms of belief and practice for some people. Moreover, swidden cultivation or nomad agriculture has changed into a permanent one gradually. There are several influential factors decreasing of a local field for paddies and availability of field for rubbers and palms plantations.

Artikel ini memberi fokus perhatian pada pengaruh agama baru (Islam dan Kristen) terhadap perubahan agroekosistem pangan pada masyarakat Dayak Loksado. Sejalan dengan kebijakan pemerintah untuk mengenalkan cara berladang modern, penyebaran agama baru (Kristen dan Islam) diasumsikan telah mendukung perubahan dari cara bertani tradisional menjadi cara bertani modern. Penelitian ini bertujuan untuk mengetahui pengaruh konversi agama dalam sistem peladangan di Loksado dan faktor-faktor yang berpengaruh dan dampak yang terjadi pada perubahan sistem tersebut. Dengan menggunakan pendekatan kualitatif, data diperoleh dari hasil wawancara mendalam yang difokuskan di Balai Padang, Desa Malinau, Kecamatan Loksado. Hasil analisis penelitian ini menunjukkan bahwa konversi ke agama baru telah merubah agroekosistem peladangan orang Loksado. Perubahan moda produksi peladangan dengan demikian dipengaruhi oleh perubahan keyakinan. Hasil studi ini juga memberi indikasi bahwa praktek peladangan berpindah di Loksado secara berangsur mengalami pergeseran ke arah peladangan menetap. Faktor-faktor perubahan antara lain disebabkan oleh berkurangnya lahan padi lokal dan luasnya areal peladangan untuk tanaman keras, terutama karet dan kelapa sawit.
\end{abstract}

Keywords: konversi; peladangan; banih; bahuma; ritual 


\section{Pendahuluan}

Penelitian tentang agroekosistem pangan dianggap penting dilakukan, karena penduduk dunia yang terus bertambah, sehingga pangan harus terus diproduksi semakin banyak untuk seluruh penduduk dunia (Zeigler 2006: 56). Dalam konteks Indonesia, penelitian agroekosistem pangan menemui urgensinya mengingat masih rentannya kemampuan dari sebagian besar masyarakat di Indonesia, dan kuatnya keinginan pemerintah untuk menjamin swasembada beras (Dabukke dan Iqbal 2014: 87-88). Di samping itu, masalah kesejahteraan petani, dan bagaimana mengembangkan pertanian yang dapat menjamin suplai pangan bagi seluruh penduduk dengan tetap memperhatikan kelestarian lingkungan, menjadi problem yang pelik.

Apa yang diinginkan oleh pemerintah untuk mencapai swasembada pangan sudah dimulai pada masa Orde Baru di tahun tujuh puluhan. Niatnya sangat mulia, bahwa penduduk Indonesia harus terjamin kebutuhan pangannya, sehingga diperlukan berbagai inovasi di bidang pertanian. Program revolusi hijau tempo dulu yang dicanangkan pemerintah Orde Baru dirasakan mampu mendongkrak produksi beras nasional, namun juga telah meninggalkan banyak persoalan. Diantara problem yang muncul adalah rusaknya ekosistem akibat pemakaian pupuk dan pestisida, punahnya beragam padi lokal, tergusurnya tenaga kerja wanita di bidang pertanian, dan tata kelola pasca produksi yang buruk.

Di Loksado, kebijakan pemerintah itu memberi implikasi pada usaha untuk mengganti agroekosistem peladangan berpindah menjadi sistem pertanian modern. Upaya itu terus berjalan hingga saat ini. Namun demikian, niat awal yang baik dari pemerintah tidak selamanya dianggap baik oleh para peladang Loksado. Sebagian peladang Loksado beranggapan bahwa hingga saat ini agroekosistem lokal yang dilandasi oleh ajaran religi lokal Aruh masih harus dipertahankan. Mereka menganggap bahwa cara tradisional dalam berladang telah terbukti menjamin persediaan pangan bagi keluarga-keluarga di Loksado. "Lihatlah ke lumbung kami, mungkin sepuluh tahun kami makan, banih (padi) itu tidak akan habis", demikian ungkap Damang Iswan, balian dari Balai Padang dalam kesempatan perbincangan dengan peneliti.

Apa yang diinginkan oleh pemerintah ternyata sejalan dengan keinginan para pengemban misi-dakwah agama-agama baru. Agama lokal Aruh yang menjadi landasan dari pengembangan agroekosistem peladangan berpindah dianggap bukanlah agama, atau bukan sebagai agama resmi negara, sehingga harus ditanggalkan oleh peladang Loksado. Sebagai akibatnya agroekosistem peladang Loksado itu telah menjadi "arena pertempuran" antara peladang tradisional Loksado yang ingin mempertahankannya, dengan pemerintah yang ingin menggantinya dengan sistem pertanian modern.

Keinginan pemerintah untuk mengganti agroekosistem peladangan berpindah itu secara tidak langsung didukung oleh aktivitas misi-dakwah agama baru, yaitu Islam dan Kristen. Bagi pengemban misi dakwah Islam 
dan Kristen, sistem pertanian modern lebih tepat menggantikan agroekosistem lama karena agroekosistem modern tidak akan lagi bersumber dari ajaran agama lokal Aruh. Jika sistem pertanian modern diterapkan, maka secara berangsur para peladang juga akan berpindah meninggalkan Aruh dan beralih ke agama Islam atau Kristen.

Dari pengamatan atas kasus yang terjadi di Loksado, ternyata keberhasilan peladang Dayak Loksado dalam menjaga ketahanan pangan, justru karena selama ini mereka cenderung bertahan dengan sistem teknologi tradisional dalam berladang yang mereka sebut dengan huma (Radam 2001; Soehadha 2010; Tsing 1998). Sebagian peladang Loksado tetap bertahan dengan sistem huma dan mengembangkan pengetahuan lokal yang berbasis pada religi Aruh yang dianutnya. Peladang berpindah di Loksado, seolah tidak peduli dengan hiruk pikuk aparat pertanian yang telah lama masuk ke wilayah Loksado untuk mengenalkan sistem pertanian yang baru. Masyarakat Dayak Loksado menggantungkan diri terutama pada pertanian padi secara subsisten. Mereka juga telah mengembangkan tanaman sayuran, palawija, dan juga tanaman keras seperti karet dan meranti.

Intervensi negara melalui program pembangunan nasional sejak Orde Baru telah mendesak kebersahajaan pola kehidupan mereka selama ini. Secara material, telah banyak bagian dari alam Pegunungan Meratus di Loksado yang menjadi objek eksploitasi, sehingga mereka tidak mampu lagi memberikan perlawanan. Ajaran dan ritual Aruh yang se- kian lama telah mengiringi kehidupan mereka didesak oleh kebijakan pemerintah, sistem pasar, dan juga gencarnya arus misi-dakwah agama baru. Dampaknya adalah ajaran dan ritual yang sebelumnya merupakan bagian dari kearifan lokal yang telah lama berakar dalam keseharian orang-orang Loksado, dipaksa bergeser menjadi sekedar khazanah budaya nasional. Banih (padi) yang dulu dianggap sakral secara berangsur telah hilang kesakralannya akibat masuknya sistem pasar (Soehadha 2010).

Intervensi negara terhadap kehidupan orang Loksado melalui kebijakan pembangunan pertanian dimulai ketika terjadi Operasi Bukit pada tahun 1967 di bawah militer. Sesuai dengan Instruksi Presiden No. 14/ Tahun 1967, militer mendukung secara penuh penyebaran agama-agama resmi (dalam hal ini agama Kristen) dan mengenalkan cara-cara baru dalam bertani terhadap masyarakat Dayak di Kalimantan (Djuweng 1996: 443493). Kebijakan untuk merubah cara berladang orang Dayak Loksado, dengan demikian telah mendapat dukungan militer sekaligus oleh upaya pengemban misi-dakwah dalam mengenalkan agama baru.

Dalam perkembangannya kini, agroekosistem Loksado juga terus dihadapkan pada perubahan masif, terutama dengan masuknya ragam tanaman industri, sehingga secara perlahan menggusur lahan-lahan peladangan bepindah yang dulu didominasi oleh tanaman padi lokal. Kelapa sawit kini menjadi tanaman yang banyak menjanjikan harapan bagi orang Loksado untuk meningkatkan pendapatan 
mereka di luar kebutuhan subsisten akan beras yang masih terus dipertahankan. Semakin beragamnya kebutuhan mereka di luar kebutuhan pangan, menyebabkan peladang Loksado harus menata ulang cara mereka berladang. Manata ulang kembali dalam berladang berarti juga harus menata ulang religiusitas mereka karena sistem keyakinan dan ritual orang Loksado berpusat pada sistem peladangan padi.

Orang Loksado yang menjadi fokus studi ini merupakan bagian dari rumpun besar suku Dayak Meratus yang tinggal di sepanjang Pegunungan Meratus, Kalimantan Selatan. Kajian tentang masyarakat Dayak Meratus antara lain telah dilakukan oleh Anna Louwenhaup Tsing (1998), Noerid Haloei Radam (2001), Soehadha (2010), dan Hartatik (2017). Kajian Tsing tentang kebudayaan dan masyarakat Dayak Meratus memusatkan perhatian pada persoalan marginalisasi orang Dayak Meratus sebagai akibat dari konstruksi kebudayaan dan politik yang dilakukan oleh pemerintah Indonesia (Tsing 1998: 5). Penelitian ini bertujuan untuk mengetahui pengaruh agama baru (Islam dan Kristen) terhadap perubahan agroekosistem pangan pada masyarakat Dayak Loksado serta faktor-faktor yang berpengaruh dan dampak yang terjadi pada perubahan sistem tersebut.

Di Loksado, sebagai akibat dari masuknya ekspansi pasar dan politik negara, aktivitas pertanian ladang berpindah (swidden agricultural) yang selama ini masih dikembangkan dapat digambarkan sebagai agroekosistem pangan yang ada "dalam kondisi bahaya" (vulnerability) (Tsing 1998: 185). Mengikuti anjuran Lees dan Bates (1984: 22), untuk mengkaji problem perubahan agroekosistem pangan dan proses adaptasi masyarakat di Loksado tersebut, maka perlu diterapkan konsep ekosistem yang mengikuti cara analisis "pendekatan bahaya" (hazard approach). Melalui perspektif itu, kegiatan manusia dan lingkungannya dalam suatu ekosistem, dipandang sebagai suatu relasi yang bersifat dinamis. Sebagai akibat dari perkembangan ekonomi modern, diasumsikan bahwa peladang Loksado dihadapkan pada sejumlah pilihan untuk menghadapi "bahaya" sebagai akibat dari perubahan ekosistem.

Dengan mengacu pada ajaran lama Aruh, dulu mereka mampu mempertahankan kemakmuran pangan Aruh atau pemujaan terhadap roh telah dianggap sebagai bagian dari cara mereka mengembangkan pertanian secara arif. Setelah cara-cara modern dalam produksi pangan sebagaimana dikembangkan oleh pemerintah masuk, secara berangsur agroekosistem lama yang dilandasi oleh agama lama itu mulai pudar. Diasumsikan bahwa masuknya cara-cara baru ini juga didukung oleh karakter agama Islam dan Kristen yang cenderung menolak keyakinan lama yang dianggap "sesat". Oleh karenanya, agroekosistem modern yang dikenalkan pemerintah cenderung lebih dianggap sesuai dengan ajaran yang dikembangkan oleh Islam dan Kristen.

Dalam hal konversi agama yang terjadi di Loksado, teori yang dikemukan oleh Hefner membantu menganalisis hal tersebut (Cogley 1993; Hefner 2000). Ia menyatakan bahwa 
konversi tidak hanya persoalan pergantian status agama, akan tetapi dipengaruhi oleh identitas, politik, dan moralitas. Sehingga kepercayaan yang dimiliki seseorang sebelum mereka konversi akan tetap melekat dan pelan-pelan ditinggalkan selama mereka beradaptasi dengan kepercayaan yang baru.

Melalui pemahaman religi sebagai sistem simbol, maka dikembangkan asumsi bahwa realitas sosial masyarakat bukanlah sesuatu yang bersifat statis, namun dalam masyarakat terjadi perubahan sebagai hasil dari interaksi simbolis yang selalu berkembang (Blumer 1969). Masing-masing individu dalam sebuah sistem sosial memiliki kedirian dan mengembangkan pemaknaan atas lingkungannya sebagai simbol-simbol dari objek interaksi, sehingga realitas sosial berlangsung secara dinamis. Melalui perspektif ini, salah satu aspek yang dikembangkan dalam pandangan fungsionalisme yang lebih memandang individu sebagai penjaga sistem sosial akan ditanggalkan. Individu bukanlah objek penderita, tetapi subjek yang mampu memberikan makna atas situasi sosial di sekitarnya. Individu dipandang sebagai pelaku aktif dalam beradaptasi dengan lingkungannya yang terus berubah. Dalam hal ini adaptasi dapat diberi pengertian sebagai "pemeliharaan terhadap suatu kondisi yang dapat menjamin eksistensi dalam suatu perubahan" (Ellen 1982: 241).

Pengertian adaptasi tersebut sejalan dengan pandangan Slobodkin (1968), Hadesty (1972), Hambur, Coelho dan Adams (1974), dan Mazess (1975) sebagaimana dikutip oleh (Ellen 1982: 243). Dalam pengertian adaptasi terkandung adanya konskuensi "..... cultural response, or open-ended process of modification, which copes with conditions for existence by selectively reproducting and extending them. (... respon budaya, atau proses tarik ulur rancang bangun, untuk mempertahankan kondisi yang dapat melindungi eksistensi, yaitu dengan cara menata ulang secara selektif dan memperluas aspek yang terkait dengannya.)."

\section{Aruh: Sistem Keyakinan Orang Loksado}

Dengan mendasarkan pada pendapat Firth (1972) seperti dikutip oleh Radam (2001: 1) yang menjadi inti dari setiap agama adalah sistem keyakinan dan sistem ritual. Artinya, bahwa sistem keyakinan dan sistem ritual akan selalu ada dalam setiap sistem keepercayaan. Sistem keyakinan selalu dianggap sebagai unsur pokok yang tidak dapat dipisahkan dari pengertian agama (religi), sebab sistem keyakinan menjadi dasar bagi umat agama dalam memandang dunianya dan menjadi pedoman tingkah laku. Sementara itu, sistem ritual menjadi simbol ekspresi dari perasaan-perasaan akan keyakinan individu dalam beragama.

Menurut Radam (2001: 147) sistem keyakinan orang Bukit di Kalimantan Selatan bersifat sinkretis. Dalam sejarahnya hingga kini, sistem kepercayaan lokal orang Dayak di Kalimantan Selatan telah bersentuhan dengan sistem keyakinan agama Hindu dan Islam. Menurutnya, terhadap keberadaan makhluk gaib di luar manusia, orang Dayak mengenal sejumlah Ilah, roh alam, dan roh nenek moyang yang mempunyai kekuasaan dan objek pemeliharaannya masing-masing. Di antara 
berbagai Ilah itu, antara lain terdapat Ilah pencipta alam raya, manusia pertama, serta tujuh tumbuhan pelindung yang dinamakan dengan Suwara. Kemudian ada ilah pencatat dan pengatur rezeki yang disebut dengan Nining Bahatara, Sangkawanang sebagai ilah (yang memberi dan menentukan kewenangan padi, serta terdapat para Hiyang dan Datu Nini, serta para nabi.

Dalam beberapa aspek, sistem keyakinan Orang Loksado juga bersifat dinamisme. Dalam keyakinan mereka, tiap pohon dan tiap tumbuhan memiliki jiwa atau memiliki roh. Dinamisme itu juga dapat kita ikuti pada mantra dan mamang yang mereka lafalkan dalam Aruh. Karena struktur sosial mereka struktur huma ladang, maka setiap komponen dari sistem mereka itu dihormati. Dalam hal ini mereka percaya bahwa dalam setiap struktur huma itu terdapat makhluk gaibnya. Dalam keyakinan mereka, makhluk-makhluk gaib tersebut ada yang baik dan ada pula yang jahat. Jika para makhluk tersebut berbuat jahat, membuat celaka manusia, maka biasanya yang demikian harus diantisipasi dengan sajen khusus. Terdapat upacara khusus yang biasanya salah satu unsurnya darah. Dahulu yang sering dipakai adalah darah manusia. Namun setelah tahun 1900an, melalui perjanjian tumbang anoi, disepakati untuk tidak akan menggunakan lagi darah manusia dan tidak ada lagi perang antar suku. Kemudian darah manusia tersebut diganti dengan darah babi, kerbau atau ayam. Orang Loksado umumnya menyajikan korban berupa binatang babi dalam setiap upacara.
Orang Loksado menyebut Aruh untuk menunjuk ritual menurut sistem keyakinan mereka. Diantara berbagai macam Aruh yang dilaksanakan oleh Orang Loksado, yang merupakan Aruh terbesar (Aruh ganal) dan dilakukan setiap tahun sekali adalah Aruh Bawanang. Pada setiap tahun mereka mengadakan Aruh Bawanang. Pada saat-saat dilaksanakan Aruh Bawanang tersebut, hampir setiap malam dalam satu minggu penuh, di setiap balai di Loksado secara terus menerus dilaksanakan rangkaian ritual (Aruh).

Istilah Bawanang berasal dari bahasa Banjar arkais, tetapi sebenarnya bagi orang Banjar sendiri pada saat ini sulit mendapatkan pengertian dari istilah itu. Dalam bahasa kuno banjar tersebut, $b a$ berarti memiliki atau memperoleh. Sementara wanang artinya sukses atau berhasil atau menang. Jadi secara harfiah bawanang berarti memperoleh kemenangan atau sukses. Disebut dengan istilah bawanang, karena Aruh tersebut terkait dengan kehidupan orang Dayak purba. Dulu, masyarakat Dayak dikenal sebagai masyarakat suku yang gemar perang. Jika mereka selesai perang antar suku dan memperoleh kemenangan, mereka mengadakan pesta besar, sesuai dengan kemenangannya. Pesta tersebut dinamakan bawanang.

\section{Bahuma: Mata Pencaharian Orang Loksado}

Hampir dari keseluruhan proses pembudidayaan tanaman di ladang oleh Orang Loksado selalu diwarnai dengan ritual. Dari proses pembukaan lahan baru, penanaman, sampai kegiatan panen selalu dapat ditemui prosesi 
Aruh (upacara) yang dilaksanakan oleh Orang Loksado. Mereka percaya bahwa setiap prosesi ritual yang mereka jalankan menurut keyakinan Kaharingan tersebut akan mendatangkan kelancaran dari seluruh usaha ekonomi mereka itu. Sebaliknya, jika mereka tidak melakukan ritual atau melanggar aturan yang telah mereka yakini kebenarannya itu, maka seluruh aktivitas ekonomi itu akan mendatangkan kegagalan dan bencana.

Orang Dayak mengusahakan tanaman pertanian pada ladang-ladang berpindah di hutan dalam sistem huma. Jarak ladang-ladang mereka dari perkampungan kurang lebih dua hingga lima kilometer. Setiap peladangan yang dibuka, hanya diusahakan tanaman utama padi selama satu kali masa panen (1 tahun 1 kali masa panen ). Dalam satu kali masa tanam padi, diusahakan untuk menanam padi tersebut mencapai waktu sekitar 5 bulan. Biasanya penanaman padi dilaksanakan pada saat musim hujan telah tiba, yaitu sekitar bulan Oktober.

Dilihat dari pola kerja mereka sehari-hari, maka dapat dikatakan bahwa orang Dayak pada dasarnya memiliki etos kerja yang cukup tinggi. Pada saat musim panen, waktu kerja yang mereka gunakan untuk mengusahakan tanaman di ladang mencapai kisaran antara sepuluh hingga dua belas jam per hari. Para wanita dan laki-laki dewasa mulai bekerja di ladang pada pukul 06.00 pagi. Mereka berangkat dari rumah mereka di perkampungan yang berjarak minimal 2 kilometer dengan cara berjalan kaki. Kadang-kadang, dengan banyaknya pekerjaan di ladang dan untuk mencegah serangan hewan-hewan liar, mereka terpaksa menginap di gubug-gubug bambu yang mereka dirikan di tengah-tengah peladangan.

Padi yang sudah dipanen dari ladang tidak serta merta digunakan oleh orang Dayak untuk memenuhi keperluan sehari-hari. Sebelum dilakukan Aruh bawanang, mereka "haram" membawa padi ke rumah dan menggunakan padi yang baru mereka panen tersebut untuk mencukupi kebutuhan makan. Jika Aruh Bawanang pada tahun ini belum mereka lakukan, maka untuk mencukupi keperluan makan sehari-hari, orang Loksado akan menggunakan beras dari sisa hasil panen tahun lalu yang mereka simpan di lumbung.

Memakan beras hasil panen sebelum dilakukan Aruh dianggap tabu karena padi yang belum diselamati dengan dengan cara melaksanakan Aruh dianggap belum sepenuhnya menjadi milik mereka. Mereka percaya bahwa semua padi yang mereka panen bukan hanya menjadi milik orang Dayak sendiri, namun sebagian padi itu kepemilikannya juga menjadi hak dari makhluk-makhluk yang lain. Agar padi yang mereka panen itu kemudian dapat menjadi milik manusia sepenuhnya, maka mereka harus melaksanakan Aruh. Dalam hal ini pemberian hak atas padi kepada makhluk lainnya dilakukan melalui salah satu prosesi dalam Aruh, yang disebut dengan babari (membagi-bagi). Babari memiliki makna bahwa orang Dayak memiliki kewajiban untuk membagi-bagi atau memberikan hak atas sebagian dari rezekinya (tanaman padi) itu kepada makhluk lain. 
Dengan demikian, pada dasarnya Aruh itu sendiri memiliki makna, bahwa orang Loksado memiliki pandangan tentang sikap bertenggang rasa dengan orang lain, bahkan dengan makhluk yang lain. Jika mereka mendapatkan rezeki atau kesenangan, maka sebenarnya diantara rezeki yang ia dapatkan itu, terdapat hak milik dari pihak lain. Hubungan antara manusia dan alam serta makhluk yang lainnya akan harmonis, jika diantara mereka saling bertenggang rasa.

Aktivitas berladang atau bahuma bagi orang Dayak Loksado adalah kegiatan yang sarat dengan muatan religi. Kata bahuma sendiri terdiri dari kata $b a$ yang berarti melakukan dan huma atau uma yang berati ibu, sang ibu yang melahirkan padi yaitu Datu Nini Kabungsuan. Dengan demikian, secara literal kata bahuma identik dengan melakukan aktivitas merawat ibu yang melahirkan padi (Soehadha 2010: 336). Aktivitas bahuma karenanya merupakan bagian penting dari tradisi Aruh orang Dayak Loksado. Setiap warga Dayak Loksado yang ingin menjalani kehidupannya harus merawat buah padi yang dilahirkan dari langit dan dipelihara oleh Datu Nini Kabungsuan. Berladang dengan demikian bukan hanya sebuah aktivitas pertanian biasa yang bernilai ekonomis bagi menjaga keberlangsungan hidup orang Dayak Loksado, tetapi juga aktivitas yang sarat dengan muatan religius.

Setiap bagian dari aktivitas peladangan padi bagi orang Dayak Loksado adalah peristiwa yang selalu dikaitkan dengan erat pada proses seseorang memperlakukan dan menghormati ibu. Ketika membuat lubang untuk menaruh benih misalnya, mereka menyebut tahapan ini dengan istilah ma ulah liang umang, membuat lubang ibu, sehingga benih padi yang ditempatkan di lubang tersebut dianggap sebagai padi induk yang merupakan keturunan dari Diyang Penambai, buah padi yang berasal dari langit. Saat benih induk tersebut telah berkembang dan berbuah, aktivitas merawat padi kemudian diistilahkan dengan besambu umang, yang berarti merawat ibu yang sedang hamil (Radam 2001: 259).

Sebagai tanaman yang dikuduskan, mitos padi bagi orang Dayak Loksado berkaitan dengan rezeki dari langit yang harus diperhatikan secara seksama berbagai proses perawatannya. Tanpa memperhatikan unsur-unsur penting perawatan tersebut, keberkahan rezeki menjadi hilang. Penyebutan padi dengan istilah diyang, secara literal berarti bidadari atau putri, mengilustrasikan penghormatan atau cara pandang yang tinggi akan keberadaan padi. Putri yang cantik tentu sangat ditunggu kedatangannya. Oleh karena itu, ketika padi ditanam oleh orang Dayak loksado maka aktivitas mereka tersebut diibaratkan seperti seorang putri yang akan melakukan perjalanan jauh guna mengarungi kehidupan dan pada akhirnya kembali dengan membawa rezeki sebagai sumber kehidupan (Soehadha 2010: 342).

Mengarungi perjalanan jauh dalam konteks ini dapat dipahami sebagai gambaran bahwa rezeki bagi orang Loksado tidaklah datang dengan sendirinya. Namun rezeki itu harus tetap dirawat dan ditanam sesuai dengan 
tradisi yang diwariskan oleh nenek moyang, bahkan jika proses penanaman itu harus dilakukan dengan berpindah-pindah sekalipun. Datuk Adam sendiri dalam mitos orang Loksado harus berpindah-pindah dan berjalan-jalan mengikuti ke mana rezeki membawanya. Saat padi ditempatkan di liang umang, maka bagi orang Loksado sesungguhnya padi tersebut sedang melakukan perjalanan jauh untuk mendapatkan hasil yang melimpah. Ketika padi telah kembali ke tempatnya semula yang ditandai dengan musim panen, maka padi tersebut telah mendatangkan rezeki dengan membawa serta teman-temannya yang melimpah.

Pengkudusan nilai padi sebagai pembawa rezeki menjadikan aktivitas berladang sebagai aktivitas religius yang mewarnai kehidupan sosial sehari-hari orang Dayak Loksado. Dari aktivitas berladang, mulai dari membuka ladang, menanam, memelihara, menuai, mendistribusikan dan mengkonsumsi padi, terbentuklah pola relasi, interaksi dan pola kepemimpinan yang berpusat pada balian sebagai pimpinan sosial keagamaan. Balian diserahi tanggung jawab untuk memimpin ritual Aruh bagi setiap proses penanaman dan perawatan padi. Aruh menjadi penting karena mitos padi yang awalnya berasal dari langit yang kemudian menjadi pangan manusia di bumi. Melalui Aruh, orang langit akan turun ke bumi guna memberkati padi yang ada di bumi. Aruh menjadi media pemujaan terhadap para pemelihara padi yang berada di langit dan menjadi simbol pengharapan peladang terhadap berkah dari segenap makhluk langit yang memelihara padi. Dengan demikian komunikasi antara peladang dengan pemelihara padi dapat terjalin dengan baik.

Salah satu alasan kenapa komunikasi antara peladang dengan para pemelihara padi di langit adalah agar terjadi proses transfer pengetahuan dari makhluk langit kepada orang di bumi terkait cara pemeliharaan padi. Dalam mitos orang Dayak Loksado, Datu Nini Kabungsuan membawa padi ke bumi dengan cara mencuri, tanpa proses transfer pengetahuan bagaimana cara pemeliharaannya. Maka dari itu, Aruh menjadi media agar padi yang pada awalnya dicuri tersebut diikhlaskan dan tetap diberkati oleh orang langit dan mereka bersedia turun ke bumi untuk mengajarkan cara memelihara dan merawat padi (Soehadha 2010: 349).

\section{Islam di Loksado}

Dalam tulisan Lindblad (1988) dan Uka Tjandrasasmita (dalam Marniati dan Sasongko 2016) disebutkan bahwa pintu gerbang masuknya Islam ke Kalimantan diperkirakan melalui Banjarmasin pada pertengahan abad ke-16. Pengaruh kerajaan Demak dalam melakukan kerjasama dengan kerajaan Banjar pada tahun 1550 menjadi awal sebab masuknya Islam. Atas pengaruh penguasa Kerajaan Demak, Pangeran Samudera sebagai Raja Banjar pada masa itu, kemudian masuk Islam. Sehingga pengaruh kekuasaan Kerajaan Banjar sebagai kerajaan Islam semakin meluas dan menyebabkan mayoritas orang Banjar kemudian turut menganut Islam.

Sementara itu penyebaran Islam ke wilayah Meratus, diperkirakan tidak berasal langsung 
dari pengaruh masuknya armada Demak. Islam menyebar di kalangan orang Meratus setelah Banjarmasin berkembang sebagai kota dagang. Pengaruh Islam muncul setelah terjadi kontak antara orang Meratus dengan para pedagang Banjar. Orang Meratus kemudian menyebut orang Banjar sebagai dangsanak tuha atau saudara tua, sebaliknya orang Banjar menyebut orang Dayak sebagai dangsanak anum atau saudara muda.

Pengaruh Islam terhadap kehidupan penduduk di Pegunungan Meratus semakin terasa pada abad ke-19, terutama pada masa perang Banjar antara serdadu pemberontak Islam Banjar di bawah Pangeran Hidayatulah dengan orang Meratus yang dimulai tahun 1859. Diperkirakan Islam mulai dipeluk oleh sebagian orang Loksado pada tahun 1860, yaitu setelah masa perang Banjar berlangsung.

Pembauran antara orang Banjar dengan orang Meratus di Loksado menyebabkan banyaknya perkawinan di antara anggota keluarga dari kedua komunitas tersebut. Perkawinan yang terjadi umumnya diikuti dengan perpindahan keyakinan orang Meratus dari religi leluhur menjadi Muslim. Penduduk Meratus yang telah menjadi Muslim, kemudian dilepas dari komunitas adatnya (Aseri 2003: 2003: 29-30). Lepasnya orang tersebut dari adat yang lama juga diikuti dengan perubahan penyebutan identitas kesukubangsaannya. Orang Dayak yang menganut Islam dan berbahasa Banjar serta hidup di bawah kerajaan Banjar lambat-laun menjadi orang Banjar, sedangkan yang tidak berpindah keyakinan ke Islam dan tidak berbahasa Banjar tetap disebut Dayak (Salim 1996: 225-226).
Pandangan ekologi individu dipengaruhi oleh kepercayaan tentang alam dan takdir manusia yang terdapat dalam keyakinan agama (Barbour 2006: 73-75; Fauzi 2007). Hasil pengamatan terhadap aktivitas para peladang di Loksado menunjukkan bahwa keyakinan religi telah mempengaruhi cara mereka berladang. Pandangan para pengemban dakwah Islam yang mengajarkan ekoteologi yang menempatkan lingkungan alam hanya sebagai sumber penghidupan manusia, tanpa menekankan aspek pelestarian lingkungan, telah menyebabkan para peladang yang telah beralih dari Aruh ke Islam cenderung agresif dalam berladang. Berikut digambarkan perubahan kosmologi sebagai akibat konversi religi, dan pengaruhnya terhadap praktik Aruh sebagai akar religi bahuma.

\section{Kristen di Loksado}

Orang Dayak di Loksado pada awalnya adalah penganut agama Balian, dimana semua sistem kepercayaan dan ritus-ritus yang berkaitan dengan kepercayaan tersebut dipimpin oleh seorang Balian. Tradisi orang Dayak Meratus ini dalam konstelasi politik agama di Indonesia tidak termasuk dalam agama yang diakui oleh pemerintah. Berbeda dengan keyakinan orang Dayak di daerah lainnya yang menjadikan tradisi mereka (Kaharingan) sebagai bagian dari Hinduisme, Dayak di Loksado mengganggap agama Balian sebagai tradisi yang berbeda. Pada era tahun 1970-an, sekelompok balian di perbukitan barat Meratus pernah mencoba meminta pemerintah untuk mengakui Balian sebagai agama, sementara 
kelompok lain di daerah perbukitan timur beranggapan bahwa agama Balian sama dengan Budhisme. Namun pada tahun 1980-an, orang Loksado mulai menggunakan istilah agama Kaharingan, meskipun menurut mereka agama Balian sebenarnya berbeda dengan Kaharingan (Tsing 1998: 400). Penggunaan istilah Kaharingan setidaknya membuat posisi orang Dayak di Loksado lebih aman dan bebas dari label sebagai masyarakat yang tidak beragama, terutama jika mengacu pada kebijakan pemerintahan Soeharto yang pada masa itu sangat keras terhadap masyarakat suku. Afiliasi ke salah satu agama yang diakui pemerintah menjadi alternatif pilihan yang dilakukan tidak hanya oleh masyarakat Loksado, tetapi juga oleh berbagai masyarakat suku lainnya di Indonesia sehingga banyak komunitas indigenous yang harus menata ulang tradisinya agar sesuai dengan agama resmi negara (Aragon 2000; Atkinson 1983; Ripert dan Schiller 1997).

Saat ini sudah banyak warga Loksado yang telah beralih dari tradisi Balian ke agama Kristen. Misi Kristen diperkenalkan di wilayah Loksado pada tahun 1967 dengan masuknya Gereja Kristen Evangelis (GKE), berbarengan dengan saat Orde Baru menata kekuasaannya. Rejim Soeharto dibangun atas fondasi penolakan terhadap komunisme dan ateisme. Masyarakat adat yang tidak diakui sistem tradisi dan kepercayaannya harus berafiliasi kepada salah satu agama resmi yang diadopsi oleh pemerintah guna menghindari tuduhan sebagai masyarakat yang tidak beragama dan berpotensi menjadi komunis. Dengan demi- kian, konversi ke salah satu agama resmi menjadi krusial dan strategi untuk bertahan hidup, a matter of sheer survival (Kipp dan Rodgers 1987). Dalam konteks masyarakat di Pegunungan Meratus, Panglima Kodam Lambung Mangkurat, Brigjen Sabirin Mochtar pada tahun 1967 pernah melakukan 'Operasi Bukit' untuk mengupayakan agar masyarakat Loksado melangkah maju, sejahtera dan terlepas dari ikatan keterasingan. Pemerintah kemudian menggagas program pendidikan, pelayanan kesehatan, pemukiman kembali dan, termasuk, mengamakan warga Meratus. Namun dalam pelaksaannya Brigjen Sabirin Mochtar merasa bahwa kegiatan tersebut tidak akan sukses jika hanya melalui operasi militer. Oleh karena itu, gerakan Operasi Bukit perlu menggandeng pihak ketiga yang merupakan lembaga non-pemerintah (Soehadha 2010: 122). Gereja Kristen Evangelis yang kemudian merespon program ini dan bersedia membantu pemerintah. Kesempatan tersebut disambut dengan baik oleh E. Saloh, ketua umum majelis Sinode GKE (1962-1968) dan berhasil melakukan pembabtisan masal pada tahun 1968 (Ukur 2002: 221-222). E. Saloh pada waktu bahkan harus berjalan kaki mendaki gunung menuju Loksado karena jalan belum terbuka seperti sekarang. Dari kontak awal tersebut kemudian dikirim pendeta pertama yang bertugas di Loksado, yaitu Pendeta Sitambodion, orang Dayak Maayan. Penugasan Sitambadion ke Loksado atas dasar asumsi bahwa orang Maayan adalah saudara tua dari orang-orang Meratus. Warga Meratus yang ingin belajar ilmu kesaktian biasanya akan 
pergi ke Tamiang Layang untuk berguru pada orang-orang Maayan. Asumsi ini terbukti berhasil memudahkan penerimaan masyarakat setempat terhadap pendeta pertama tersebut.

Gereja Kristen Evangelis berhasil menginisiasi pelayanan pendidikan dan kesehatan, sesuai dengan spirit developmentalisme orde baru. GKE berhasil membangun sekolah dasar kristen dan mengirim anak-anak Meratus untuk meraih jenjang pendidikan yang lebih tinggi di Banjarmasin. Pendidikan lanjutan tersebut diprioritaskan antara lain ke arah pendidikan guru, keperawatan dan kependetaan. Anak-anak didik ini pada gilirannya kemudian kembali ke Meratus untuk memberikan pelayanan pada masyarakat dan membangun Meratus. Sisi lain yang juga membantu penerimaan terhadap kehadiran pendeta adalah bahwa pendeta datang menawarkan program kesehatan dan membawa obat-obatan. Dengan demikian, pendeta kemudian dianggap menjadi 'Balian alternatif dengan obat medis dan doa-doanya.

Meskipun pada awalnya kegiatan keagamaan Gereja Kristen Evangelis dilakukan di Balai warga Meratus, namun pada tahun 1978 GKE berhasil membagun sebuah gereja yang berbentuk balai di suatu tempat yang diberi nama Pantai Harapan. Gereja di lokasi tersebut kemudian ditinggalkan dan dibangun gereja baru di Loksado pada tahun 1980-an. Gereja yang terakhir ini kemudian dipindahkan lagi seberang jalan dengan bentuk bangunan permanen pada tahun 2003 dan diberi nama Efrata. Pada dekade 1980-an di Loksado juga hadir gerakan Kristen lain, yaitu Gereja Bethel
Indonesia. Secara teologis, GBI termasuk gereja yang beraliran karismatik fundamentalis dan mendapat dukungan finansial dari Amerika Serikat.

Kehadiran Kekristenan di Loksado tentu bermuara pada berbagai perubahan mendasar pada tradisi masyarakat Dayak di Loksado. Perubahan tersebut mulai dari ditinggalkannya budaya hidup di rumah Balai hingga pada budaya peladangan yang tidak lagi mempertahan tradisi nenek moyang. Hidup di Balai bagi orang dayak Loksado adalah simbol eratnya hubungan masyarakat. Di dalam Balai setiap keluarga dapat saling bergaul, berkomunikasi dan bekerja sama. Berpindahnya masyarakat ke rumah-rumah biasa dan masuknya mereka ke agama Kristen jelas meruntuhkan tradisi yang sudah berjalan lama. Ditambah lagi bahwa pendeta selalu menegaskan bahwa orang-orang yang masih tinggal di Balai adalah penganut agama lokal yang bodoh dan terbelakang. Oleh karenanya, orang Dayak yang telah menjadi penganut agama Kristen harus membedakan diri mereka dan tinggal dipemukiman sendiri. Konsekuensinya perlahan-perlahan tradisi nenek moyang ditinggalkan dan identitas orang Dayak Loksado yang Kristen terbangun.

\section{Pengaruh Islam dan Kristen di Loksado}

Dengan ditinggalkannya kepercayaan Aruh menyebabkan ditinggalkannya penghormatan terhadap kawasan sakral. Beberapa lahan yang dulu dipercaya sebagai wilayah keramat menurut kepercayaan Aruh, tidak lagi di- 
perhatikan keberadaannya. Rasa hormat terhadap segenap makhluk, seperti terhadap pohon dan wilayah tertentu, serta pamali berladang dan membakar lahan pada hari-hari tertentu mulai ditinggalkan. Perubahan pandangan kosmis akibat konversi religi telah menyebabkan perubahan cara berladang yang mengutamakan harmoni, menjadi cara berladang yang agresif untuk menundukkan dan menguasai alam.

Sejalan dengan pemikiran Hefner yang meyatakan bahwa konversi tidak hanya berkenaan dengan masalah pergantian status agama, akan tetapi konversi dipengaruhi oleh identitas, politik, dan moralitas. Selain itu, konversi tidak membuat seseorang berubah secara total akan tetapi pengaruh kepercayaan dan budaya sebelumnya masih melekat pada seseorang tersebut dan pelan-pelan mereka mulai beradaptasi dengan agama barunya. Yang terjadi di Loksado khususnya peladang Muslim sudah tidak lagi memiliki kewajiban terlibat dalam ritual Aruh bawanang di balai, sehingga mereka juga sudah tidak lagi memiliki ujug atau kamar keluarga di dalam balai. Meninggalkan agama lama berarti juga melepas keterikatan mereka terhadap sistem sosial balai dan ikatan adat. Akan tetapi untuk saat ini orang-orang Islam di sana hanya dilibatkan dalam membantu proses memasak dan mendapatkan upah memasak.

Penyelenggaraan berbagai ritual peladangan dan ritual kehidupan lainnya seperti perkawinan, berkurban, dan kematian tidak lagi diserahkan kepada lembaga balai. Peran balian digantikan oleh rois sebagai pemimpin
Islam. Mantera-mantera atau mamangan Aruh yang dilafalkan oleh balian dalam berbagai ritual yang mengawal aktivitas bahuma, kemudian diganti dengan doa-doa berbahasa Arab yang dilafalkan oleh seorang rais. Hal tersebut juga dilakukan ketika peladang Muslim selain digunakan pupuk dan pestisida untuk menyuburkan tanaman, juga masih digunakan ritual bahuma yang berisi doa-doa khusus untuk merawat tanaman. Namun intensitas ritual bahuma yang dilaksanakan tidak sebanyak ritual yang dilakukan oleh peladang yang masih menganut Aruh. Ritual bahuma oleh peladang Muslim hanya dilakukan pada saat menugal dan pada saat tanaman diserang penyakit.

Di samping itu, mereka juga memiliki pilihan lain dalam mengusahakan tanaman padi. Banih barat atau benih lokal dengan masa panen enam bulan tidak lagi menjadi pilihan utama sebagai tanaman peladangan. Agar padi lebih cepat panen, maka banih ringan yang hanya berumur tiga bulan untuk panen kemudian secara berangsur menjadi tanaman yang menggeser banih barat. Pilihan terhadap banih ringan semakin diperkuat karena konversi agama dari Aruh ke Kristen dan Islam. Menanam padi kemudian tidak terikat lagi dengan berbagai ritual. Banih ringan tidak perlu dikawal dengan Aruh, karena banih ringan bukanlah padi sakral keturunan Diyang Panambi. Kebijakan Pemerintah dengan memasukkan berbagai program pertanian, seperti pengenalan tanaman padi unggul, anjuran berladang menetap, pengenalan bibit tanaman industri turut mempercepat perubahan agroekosistem peladangan di Loksado. 


\section{Perubahan Peladangan Berpindah ke Peladangan Menetap}

Dalam mengusahakan pertanian dengan sistem peladangan berpindah, orang Dayak memiliki sistem pengetahuan dan cara-cara tertentu dalam menjaga ekosistem, sehingga cara pembudidayaan pertanian dengan sistem itu tidak mengakibatkan kebakaran hutan atau mengganggu ekosistem. Justru dalam sistem peladangan yang mereka usahakan tersebut telah membantu memperbaiki kesuburan tanah.

Peladangan berpindah seperti yang dipraktekkan oleh orang Loksado tidak akan mengakibatkan hutan menjadi gundul, karena peladangan berpindah dilakukan dengan sistem rotasi. Rotasi dalam penggarapan ladang berpindah minimal dilaksanakan dalam waktu 8-10 tahun, dengan perhitungan dari titik awal mulai membuka lahan. Setiap pembukaan tanah baru ditanami 1 kali padi dan tumpangsari dalam waktu 1 tahun. Pemilihan tanah yang akan dibuka terkait dengan sistem religi, di mana pembukaan setiap ladang yang baru didahului dengan upacara adat. Setelah ladang selesai ditanami, mereka tidak meninggalkan begitu saja, melainkan menanam kembali dengan tanaman-tanaman keras, seperti kayu manis, karet, miranti, dan sebagainya.

Cara membakar semak-semak yang akan dijadikan lahan juga tidak menyebabkan kebakaran hutan. Ketika mereka bermaksud untuk membuka lahan umumnya mereka juga telah mulai menjaga calon ladang itu setiap hari dengan cara tinggal di gubug-gubug yang telah mereka bangun. Jadi mereka tetap dapat mengendalikan api agar tidak membakar pohon-pohon lainnya di sekeliling ladang yang akan dibuka.

Orang-orang Loksado bertanam padi pada lahan di ladang-ladang yang miring. Bagi orang luar, cara budidaya pada lahan miring ini seringkali dianggap kurang baik, karena dapat menimbulkan tanah longsor. Namun kenyataannya tidak pernah terdengar bahwa pada ladang-ladang miring yang diusahakan oleh orang Dayak terjadi kelongsoran tanah. Di kalangan petani Dayak Loksado, peladangan padi pada lahan miring mempunyai manfaat, karena dapat menjauhkan tanaman padi dari serangan hewan-hewan liar. Beberapa binatang hutan yang sering mengganggu tanaman petani, terutama babi hutan, akan kesulitan menjangkau tanaman yang diusahakan di lahan-lahan miring tersebut.

Di sekeliling peladangan (huma) tempat budidaya padi umumnya juga diusahakan tanaman palawija dan sayuran seperti labu, cabai, ketela pohon, dan sebagainya. Penanaman palawija dan sayuran di sekeliling tanaman pokok (padi) itu dimaksudkan oleh petani sebagai "radar". Sayuran dan palawija yang ditanam di pinggir-pinggir tanaman pokok, selain bermanfaat sebagai tanaman tumpangsari, ia juga berfungsi untuk menangkal serangan hewan liar dan hama lainnya yang akan mengganggu tanaman pokok (padi). Jika tikus atau binatang pengganggu lainnya mulai makan tumbuhan di sekeliling padi, berarti para petani harus siap, bahwa telah ada tanaman padi mereka sedang terancam oleh hewan pengganggu. 
Cara menangkal binatang pengganggu juga dilakukan dengan cara menanam tanaman bunga yang berwarna mencolok. Para petani umumnya menanam cabai dan bunga buntut kutang ( bunga ekor anjing ) yang berwarna mencolok, seperti warna merah, kuning, dan hijau. Penanaman bunga-bunga seperti itu memiliki tujuan untuk mencegah serangan hama berupa serangga dan burung pipit Pembudidayaan cabe dan bunga-bunga yang mencolok di sela-sela tanaman padi, mempunyai maksud agar serangga dan burung pipit tidak menyerang langsung tanaman padi. Bunga-bunga dengan warna yang mencolok akan disenangi oleh serangga dan burung pipit, sehingga jika binatang pengganggu itu datang, mereka akan menyerang bunga dan cabai, bukan menyerang padinya. Di samping itu, hasil dari tanaman cabe dan bunga tersebut juga memiliki manfaat lain. Hasil dari cabe dapat digunakan untuk kebutuhan dapur, dan sebagian lainnya dapat dijual. Sementara itu bunga-bunga yang ditanam secara tumpangsari dengan padi, biasanya dimanfaatkan untuk perlengkapan acara ritual Aruh.

Akan tetapi, sistem peladangan berpindah memiliki dampak negatif bagi alam. Pertama, sistem ini mengakibatkan kekeringan di musim kemarau dan banjir pada musim hujan. Kedua, tingkat kesuburan tanah menurun. Ketiga, mengganggu kehidupan hewan dan tumbuhan yang hidup pada lahan tersebut. Keempat, menurunkan keanekaragaman hewan dan tumbuhan. Oleh karena itu, orangorang Loksado mulai memikirkan ulang sistem peladangan berpindah atas dasar pertimbang- an bahaya-bahaya tersebut dan berangsurangsur mulai menggati dengan sistem peladangan menetap.

\section{Pengaruh Tanaman Industri: Karet dan Kelapa Sawit}

Arus kapitalisme di Loksado antara lain dapat dilihat dari masuknya tanaman industri berupa karet dan Kelapa Sawit. Masuknya kedua tanaman keras tersebut turut merubah pola peladangan Orang Loksado secara berangsur. Karet telah masuk dan ditanam orang Loksado secara senagaja sejak tahun delapanpuluhan, sementara kelapa sawit baru masuk ke Loksado pada tahun 2010.

Menurut Soehadha (2010) kecenderungan untuk menempatkan tanaman keras sebagai produksi ladang "lapis kedua" setelah padi, lambat laun telah menggeser eksistensi agroekosistem pahumaan menjadi agroekosistem baru yang menyertakan tanaman keras. Pergeseran agroekosistem peladangan tersebut telah mengukuhkan proses kapitalisasi dalam cara berladang. Setelah uang tunai menjadi alat utama dalam petukaran ekonomi di Loksado, terdapat kecenderungan di kalangan peladang yang menganggap bahwa tanaman keras seperti karet (Hevea brasiliensis), kayu manis (Zinanonum zeylanikum), bambu (Bamboo), dan kemiri (Alieurites javanica), dan kelapa sawit (elais) sebagai tanaman "lapis kedua" yang juga diusahakan di ladang.

Budidaya karet yang dilakukan oleh peladang Loksado merupakan bagian dari perkembangan budidaya karet yang telah 
diperkenalkan sejak zaman kolonial Belanda. Orang Dayak di sepanjang aliran sungai Mahakam dan Barito, serta Hulu Sungai telah mulai tertarik menanam karet pada tahun 1920 (Lindblad 1988: 59). Diperkirakan orang Loksado mulai menanam karet setelah mereka mendapatkan bibit karet dari orang Banjar dan orang Dayak yang tinggal di Pegunungan Meratus di wilayah Hulu Sungai Utara.

Berkembangnya tanaman karet di Loksado tidak terlepas dari kenyataan bahwa tanaman tersebut sangat cocok dikombinasikan dengan budidaya tanaman subsisten padi ladang. Karet (Hevea brassiliensis) ditanam terutama oleh penduduk yang memiliki status sosial ekonomi yang tinggi, karena menguasai tanah yang luas. Tanaman karet terutama dibudidayakan oleh anggota keluarga dari para pemimpin tradisional Loksado, seperti oleh para penghulu dan anggota keluarganya. Dalam perkembangannya, baturih karet telah menjadi sumber ekonomi tambahan bagi sebagian peladang Loksado, di samping batilah atau mengolah bambu (Bambusa), mengambil rotan (Calamus platyacantos), dan kayu manis (Cinanamomum casia), serta mengolah tanaman keras lainnya.

Transformasi dalam cara bahuma masyarakat Loksado juga ditandai oleh masuknya karet sebagai tanaman "komoditas" non-padi tersebut. Bagi peladang, baturih karet telah menjadi sumber untuk memperoleh uang tunai. Uang tunai sudah menjadi kebutuhan harian bagi orang Loksado. Di samping karena banyak barang kebutuhan rumah tangga yang sudah harus dipenuhi dengan cara membeli, uang tunai juga diperlukan untuk kegiatan berladang padi. Tidak semua pekerjaan di ladang cukup diselesaikan dengan baarian atau bergotong royong menggunakan tenaga kerja keluarga. Kini telah menjadi kebutuhan penduduk untuk mempekerjakan tenaga upahan, meskipun cara baarian masih tetap dipertahankan.

Terjadinya perubahan dalam aktivitas peladangan atau bahuma yang diakibatkan oleh masuknya tanaman komoditas Karet di Loksado itu, sejalan dengan analisis Jacob Mallinckrodt. Dalam analisis Mallinckrodt (1928: 79-80) sebagaimana diungkapkan oleh Van Dijk (1983: 366) disebutkan bahwa menanam karet telah menimbulkan karakter individualisasi di kalangan penduduk hulu sungai. Mallinckrodt berkesimpulan bahwa pada saat karet mulai ditanam, telah muncul tuan-tuan tanah yang tidak menyadap pohon karetnya sendiri, namun telah mulai menggunakan buruh upahan.

Munculnya kebiasaan menggunakan tenaga upahan dalam baturih atau menyadap karet, disebabkan pandangan peladang yang masih menganggap karet sebagai mata pencaharian lapis kedua setelah berladang padi atau bahuma. Menurut Velsing (1925: 226-227) sebagaimana dikutip (Van Dijk 1983: 366), tetap bertahannya penduduk di wilayah Hulu Sungai menjadikan kegiatan bahuma sebagai mata pencaharian utama, dan karet sebagai tanaman lapis kedua, karena karet dianggap hanya dapat menjadi komoditas yang menguntungkan pada saat tertentu, yaitu ketika situasi pasar benar-benar meng- 
untungkan. Di luar situasi pasar yang mendukung, justru karet bisa menjadi penyebab bencana. Oleh karena itu tidak mengherankan, ketika pada tahun 1921 dan 1922 pasaran karet dunia ambruk, wilayah Hulu Sungai tetap dapat mempertahankan kemakmuran ekonominya.

Bagi peladang yang masih menganut Aruh, meskipun baturih karet dan mengusahakan tanaman non-padi lainnya dianggap dapat memberi tambahan untuk mencukupi kebutuhan ekonomi, namun kegiatan tersebut hanya dianggap sebagai kegiatan pelengkap. Sebagai kegiatan pelengkap, maka baturih karet umumnya tidak dikerjakan sendiri oleh peladang. Baturih karet biasanya dilakukan dengan melibatkan tenaga upahan dengan cara bagi hasil. Peladang akan menghentikan semua pekerjaan baturih dan kegiatan mengolah tanaman keras yang lain, jika padi di ladang mencapai masa pertumbuhan yang membutuhkan penanganan khusus yang harus disertai Aruh.

Karet umumnya hanya ditanam oleh peladang yang memiliki ladang yang luas. Hal itu disebabkan untuk bertanam karet, diperlukan paling cepat delapan tahun untuk bisa mulai mengambil getahnya. Bagi peladang yang hanya memiliki luas lahan yang terbatas, penanaman karet dianggap dapat menggangu rotasi peladangan padi. Di kalangan peladang penganut Aruh, karet tidak dianggap sebagai tanaman utama, dan hasil karet tidak dianggap sebagai "rejeki", melainkan sebagai "perolehan". Oleh karena itu, bagi peladang tradisional yang menguasai lahan terbatas, cenderung menghindari bertanam karet.
Selain ditanam oleh para peladang yang menguasai lahan yang luas, ada kecenderungan karet ditanam oleh para peladang yang sudah meninggalkan religi Aruh. Bagi peladang yang sudah beralih ke religi baru, bertanam karet dirasakan lebih menguntungkan, terutama untuk menghasilkan uang tunai. Tidak ada masalah bagi peladang yang telah menganut religi baru untuk bertanam karet, meskipun ia hanya menguasai lahan terbatas, sebab tidak ada kewajiban lagi baginya untuk menanam padi.

Keuntungan bertanam karet terutama terletak pada masa memanen yang cukup panjang. Setelah delapan tahun, getah karet dapat diambil terus hingga berumur dua puluh tahun. Bertanam karet (Hevea brasiliensis) sangat menguntungkan, karena dapat ditanam untuk mengisi kembali ladang padi atau pahumaan yang sudah tidak produktif. Tanaman karet (Hevea brasiliensis) tidak membutuhkan perawatan khusus. Peladang umumnya mendapat benih karet dari penduduk yang sebelumnya sudah bertanam karet. Di samping itu, banyak di antara peladang yang mendapat benih dengan cara memungut biji dari perkebunan di sekitarnya. Kebun karet (Hevea brasiliensis) rintisan pertama di Loksado umumnya dimiliki oleh orang Banjar.

Pada tahun 2010 orang Loksado mulai diperkenalkan tanaman kelapa sawit. Benih kelapa sawit diperoleh dari bantuan pemerintah. Menurut Damang Iswan bertanam kelapa sawit kini lebih menguntungkan daripada karet. Mereka sudah mulai memanen kelapa sawit dalam dua tahun terakhir. 
Damang Iswan mengaku dapat memanen kelapa sawit dua kali dalam satu bulan dan mendapat dua ton kelapa sawit. Satu kilogram kelapa sawit dibeli para tengkulak dengan harga 1200 rupiah. Kira-kira dalam dua bulan ia bisa memperoleh penghasilan lima juta rupiah dari kelapa sawit.

\section{Kesimpulan}

Kehadiran agama baru Islam dan Kristen memutus mata rantai pentingnya Aruh sebagaimana yang dipahami oleh orang Dayak. Menjadi Kristen pada akhirnya identik dengan meninggalkan tradisi Aruh dan beralih ke gereja untuk mencari keberkahan baik saat akan memulai peladangan hingga ke musim panen. Gereja dan petugas gereja mengantikan landskap kosmologi keyakinan orang Loksado dan membentuk konstruksi identitas mereka yang baru. Kehadiran kekristenan dalam hal ini jelas melepaskan, detached, orang Loksado yang Kristen dengan akar keyakinan leluhur mereka.

Hal itu juga terjadi ketika orang Loksado menjadi Muslim, ritual Aruh yang cenderung dianggap sebagai ritual yang mendekati perbuatan syirik. Oleh karenanya menjadi Islam berarti merubah rangkaian ritual yang mengawal peladangan padi. Meskipun tidak sepenuhnya Muslim Loksado meninggalkan seluruh ritual dan nilai Aruh, namun kosmologi pandangan tentang padi, ladang telah berubah. Sebagai akibatnya mereka juga mulai terbuka untuk merubah tanaman utama peladangan mereka. Padi meskipun masih ditanam, namun tidak mesti menjadi tanaman utama. Padi kemudian hanya menjadi sekedar tanaman subsistensi untuk memenuhi kebutuhan pangan keluarga.

Seiring dengan perkembangan kehidupan sosial mereka, kebutuhan di luar pangan kemudian menjadi kebutuhan yang memerlukan pemuas lebih banyak dan dominan. Oleh karena itu mereka juga memerlukan sumber pendapatan dari peladangan mereka dengan membudidayakan tanaman peladangan yang menjanjikan hasil yang lebih banyak. Kemiri, karet, dan kelapa sawit kemudian menjadi pilihan untuk mendapat hasil berupa uang tunai guna memenuhi kebutuhan di luar pangan yang semakin beragam.

Konversi ke agama baru dengan demikian telah merubah agroekosistem peladangan Orang Loksado. Sebagai kesimpulan akhir, penelitian ini menggarisbawahi bahwa perubahan moda produksi peladangan dengan demikian dipengaruhi oleh perubahan keyakinan. Kebutuhan yang semakin beragam, orientasi produksi yang bergeser dari subsistensi ke surplus produksi, intervensi pemerintah, telah mendorong Orang Loksado meninggalkan Aruh dan meninggalkan agroekosistem peladangan yang lama.

Hasil studi ini juga memberi indikasi bahwa praktek peladangan berpindah di Loksado secara berangsur mengalami pergeseran ke arah peladangan menetap. Faktor-faktor perubahan antara lain disebabkan oleh berkurangnya lahan padi lokal dan luasnya areal peladangan untuk tanaman keras, terutama karet dan kelapa sawit. Konversi agama dan kebijakan pemerintah tentu semakin memperkuat pergeseran pola peladangan dari 
peladanagan berpindah ke peladangan menetap di masa mendatang. $\square$

\section{Daftar Pustaka}

Aragon, Lorraine V. 2000. Fields of Lord: Animism, Christian Minorities, and State Development in Indonesia. Honolulu: University of Hawai'i Press.

Aseri, F. 2003. Perilaku Etnis dan Potensi Konflik di Kalimantan Selatan. Banjarmasin: Pusat Penelitian IAIN Antasari.

Atkinson, Jane Monnig. 1983. "Religion in Dialogue: The Construction of an Indonesian Minority Religion." American Ethnologist 10(4):684-696.

Barbour, I. G. 2006. Isu dalam Sain dan Agama. Yogyakarta: UIN Sunan Kalijaga.

Blumer, H. 1969. Symbolic Interactionism; Perspective and Method. New Jersey: Prentice-Hall.

Cogley, Richard W. 1993. Conversion to Christianity: Historical and Anthropo logical Perspectives on a Great Trans formation. ed. R. W. Hefner. Berkeley: University of California Press.

Dabukke, Frans B. M. and Muhammad Iqbal. 2014. "Kebijakan Pembangunan Pertanian Thailand, India, dan Jepang serta Implikasinya." Jurnal Analisis Pertanian 12(2):87-101.

Van Dijk, C. 1983. Darul Islam: Sebuah Pemberontakan. Jakarta: Grafiti Pers.

Djuweng, Stepanus. 1996. "Orang Dayak, Pembangunan, dan Agama Resmi." dalam Kisah dari Kampung Halaman, ed. S. Djuweng. Yogyakarta: Interfidei.

Ellen, R. 1982. Environment, Subsistence, and System: The Ecology of Small-Scale
Social Formations. Cambridge: Cambridge University Press.

Fauzi, A. M. 2007. "Etika Lingkungan: Sebuah Kritik terhadap Etika Antroposentrisme." Jurnal Refleksi 5:190-204.

Hartatik. 2017. Jejak Budaya Dayak Meratus dalam Perspektif Etnoreligi. Yogyakarta: Penerbit Ombak.

Hefner, Robert W. 2000. Civil Islam: Muslim and Democratization in Indonesia. Princeton: Princeton University Press.

Kipp, Rita Smith and Susan Rodgers. 1987. Indonesian Religions in Transition. Tucson: The University of Arizona Press.

Lees, S. H. and D. G. Bates. 1984. "Environmental Events and The Ecology of Cumulative Change." dalam The Ecosystem Concept in Anthropology, ed. E. F. Moran. Colorado: Westview Press.

Lindblad, J. Thomas. 1988. Between Dayak and Dutch. Dordrech-Holland; ProvidenceUSA: Foris Publications.

Mallinckrodt, Jacob. 1928. "Het Adatrecht van Borneo."

Marniati and Agung Sasongko. 2016. "Kapan Islam Masuk Ke Kalimantan?” Republika Online - Khazanah. Retrieved February 25, 2018 (https://republika.co.id/ berita/dunia-islam/islamdigest/16/09/01/octbvq313-kapanislam-masuk-ke-kalimantan).

Radam, N. H. 2001. Religi Orang Bukit. Yogyakarta: Semesta.

Ripert, Blandine dan Anne Schiller. 1997. Small Sacrifices: Religious Change and Cultural Identity among the Ngaju of Indonesia. Oxford, New York: Oxford University Press. 
Salim, H. 1996. Islam Banjar, Relasi Antar Etnik dan Pembangunan. Yogyakarta: Interfidei.

Soehadha, Moh. 2010. "Aruh Menjaga Beras Kami: Religi, Subsistensi dan Kapitalisme Negara dalam Pengembangan Produksi Pangan di Loksado, Kalimantan Selatan." Universitas Gadjah Mada, Yogyakarta.

Tsing, Anna Louwenhaup. 1998. Di Bawah Bayang-bayang Ratu Intan: Proses Mar- ginalisasi pada Masyarakat Terasing. Jakarta: Yayasan Obor Indonesia.

Ukur, F. 2002. Tuaiannya Begitu Banyak: Sejarah Gereja Kalimantan Evangelis Sejak Tahun 1835. Jakarta: BPK Gunung Mulia.

Zeigler, Robert. 2006. "Rice Research and Development." in Revitalisasi Pertanian dan Dialog Peradaban, terj. Sutanto. Jakarta: Penerbit Buku Kompas. 